Creative Commons User License: CC BY-NC-ND

Abstracted by: EBSCOhost, Electronic Journals Service (EJS), Google Scholar, Journal Seek, Scientific Commons,

Food and Agricultural Organization (FAO), CABI and Scopus

http://eoi.citefactor.org/10.11226/v23i2
Journal of Agricultural Extension

Vol. 23 (2) April, 2019

ISSN(e): 24086851; ISSN(Print); 1119944X

http://journal.aesonnigeria.org

http://www.ajol.info/index.php/jae

Email: editorinchief@aesonnigeria.org

\title{
Climate Change Adaptation Strategy for Sustainability and Food Security of Cassava Farming Households in Lampung, Indonesia
}

https://dx.doi.org/10.4314/jae.v23i2.14

\section{Murniati, Ktut}

Agribusiness Department, Faculty of Agriculture, University of Lampung, Indonesia

Corresponding author : ktutmurniati@gmail.com, Phone : +62-89611147335

\section{Widjaya, Sudarma}

Agribusiness Department, Faculty of Agriculture, University of Lampung, Indonesia Email : sudarma.wijaya@fp.unila.ac.id, Phone : +62-811729493

\section{Rabiatul, Adawiyah}

Agribusiness Department, Faculty of Agriculture, University of Lampung, Indonesia Email: adawiyahrabiatul81@yahoo.co.id, Phone : +62-85269027980

\section{Listiana, Indah}

Agribusiness Department, Faculty of Agriculture, University of Lampung, Indonesia Email: indahlistiana@yahoo.com, Phone : +62-8127956566

\section{Abstract}

Climate change causes significant impact on fluctuating agricultural production and food security. This study aimed to assess farmer's adaptation strategies to the impact of climate change in cassava farming and to analyze food security level of cassava farming households. The research was conducted in Gunung Agung Village and Gunung Batin Village, Terusan Nunyai Subdistrict, Central Lampung Regency. A total of 66 cassava farmers were selected through simple random sampling. Data analysis applied were descriptive analysis of food security level according to the definition of FAO and Ordinal Logit (Ologit) analysis. Results showed that an average of 5 climate change adaptation strategies were applied by cassava farmers. Food security level of majority of casava farming households was found to fall into the less secure category. Climate change adaptation strategy (1.56), land size (5.36), and price of rice (-0.004) were identified to affect food security of cassava farming households.

Key words: Adaptation strategy, cassava production, food security

\section{Introduction}

As an agricultural country, the agricultural sector plays an important role in the national economy in Indonesia. It is indicated by the large number of people living and working in the agricultural sector as well as numerous national products originated from agriculture (Quincieu 2015; Rahmah 2017). Agriculture is closely related to climate change, that is, a condition marked by changes in world climate pattern and results in unpredicted weather phenomena. Climate change happens due to changes in climate variables, such as temperature and rainfall that continuously occur over 
Creative Commons User License: CC BY-NC-ND

Abstracted by: EBSCOhost, Electronic Journals Service (EJS), Google Scholar, Journal Seek, Scientific Commons,

Food and Agricultural Organization (FAO), CABI and Scopus
Journal of Agricultural Extension

Vol. 23 (2) April, 2019

ISSN(e): 24086851; ISSN(Print); 1119944X

http://journal.aesonnigeria.org

http://www.ajol.info/index.php/jae

Email: editorinchief@aesonnigeria.org

http://eoi.citefactor.org/10.11226/v23i2

long period of 50 to 100 years.

Agriculture is a sector that contributes to food supply and always deals with many problems, such as problems in ecology, economy, social, cultural, and problems regarding political policy. In relation to the agricultural sector, climate change causes significant impact on fluctuating agricultural production, particularly food production (Ali et al., 2017). Climate change leads to both direct and indirect impacts on agricultural activity, such as drought which decreases agricultural production, especially those related to food production (Kirby et al., 2016). This situation will later have implication for social welfare. As well as threatening the sustainability of food security. Food and Agriculture Organization (FAO) indicated that climate change is the most serious threat to the sustainability of food security (FAO, 2016).

This condition of climate change leads to huge impact on the sustainability of agricultural productivity in Indonesia, particularly food that is consumed as staple food for Indonesian people. Besides, its impact on the agricultural sector, climate change also has impact on food security (Hakim \& Herdiansyah, 2017). Decrease in agricultural production due to climate change impacts on the decreasing food availability, and reducing people's access to food, resulting in the declining level of food security. However, sufficient food availability at macro level (national/province and regency/city) does not guarantee adequate food availability and consumption at household and individual level. Domestic cassava production only reaches 8.266.265 tons. Therefore, this situation will have impact on food security at national, household and individual levels (Saediman et al., 2016).

Lampung Province is the largest cassava production centre in Indonesia. Hence, this province is not spared by the threat of climate change which causes declining cassava production. Consequently, an adaptation strategy is required to face the threat of climate change impact to maintain production sustainability and food security of cassava farming households. Therefore, the objectives of this study are to analyse farmers' adaptation strategies to climate change impact in farming, to analyse food security level, to analyse the impact of climate change adaptation strategies and assess other factors affecting food security of cassava farming households.

\section{Methodology}

Research location was selected purposively: Central Lampung Regency, Terusan Nunyai Subdistrict in Gunung Batin Village and Gunung Agung Village. This location $\left(105^{\circ} 45^{\prime}-103^{\circ} 48^{\prime}\right.$ EL and $3^{\circ} 45^{\prime}-6^{\circ} 45^{\prime} \mathrm{SL}$ ) was chosen with consideration that the area is cassava production center in Lampung Province. Sixty-six cassava farmers were selected from 2 villages using simple random sampling technique. This study was conducted from June to August 2017.

Descriptive analysis was employed in explaining the adaptation strategy already applied by farmers to anticipate climate change. Food security level of cassava farming households was determined by measuring four aspects, namely food availability, food stability, food accessibility, and food quality as defined by FAO and has been applied by Research Center of PopuplationLIPI. There are three categories generated from this measurement, those that are food secure, less secure, and food insecure as presented in Figure 1. 
Creative Commons User License: CC BY-NC-ND

Abstracted by: EBSCOhost, Electronic Journals Service (EJS), Google Scholar, Journal Seek, Scientific Commons,

Food and Agricultural Organization (FAO), CABI and Scopus

http://eoi.citefactor.org/10.11226/v23i2
Journal of Agricultural Extension

Vol. 23 (2) April, 2019

ISSN(e): 24086851; ISSN(Print); 1119944X

http://journal.aesonnigeria.org

http://www.ajol.info/index.php/jae

Email: editorinchief@aesonnigeria.org

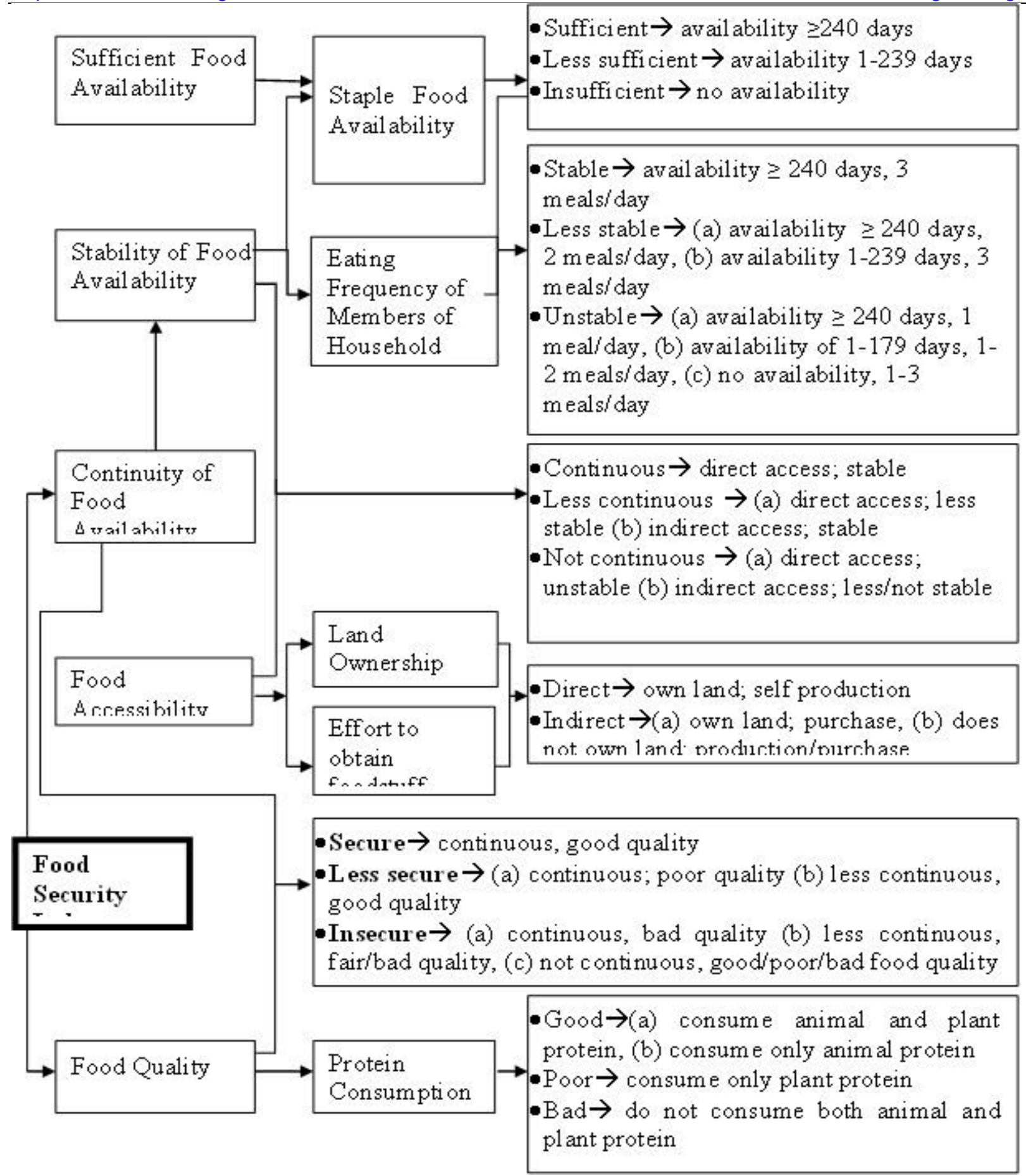

Figure 1: Method to measure of household food security index

\section{Results and Discussion}

\section{Farmer's Adaptation Strategy to the Impact of Climate Change}

Table 1 shows that the adaptation strategies used by farmers included: more intensive use of manure, reducing the use of chemical input, increasing weeding intensity, planting in early rainy season, use the recommended planting distance, scheduling of harvesting period, changing the planting time and more discipline in applying plant rotation. 
Creative Commons User License: CC BY-NC-ND

Abstracted by: EBSCOhost, Electronic Journals Service (EJS), Google Scholar, Journal Seek, Scientific Commons,

Food and Agricultural Organization (FAO), CABI and Scopus
Journal of Agricultural Extension

Vol. 23 (2) April, 2019

ISSN(e): 24086851; ISSN(Print); 1119944X

http://journal.aesonnigeria.org

http://www.ajol.info/index.php/jae

Email: editorinchief@aesonnigeria.org

http://eoi.citefactor.org/10.11226/v23i2

Table 1: Adaptation strategy to climate change

Climate change adaptation strategy

Percentage (\%)

\begin{tabular}{lr}
\hline Adjust planting time & 100,00 \\
Usage of agreed spacing & 100,00 \\
Increasing the intensity of land cleaning & 86,36 \\
Reducing the usage of chemical inputs & 83,33 \\
Application of minimum tillage & 78,79 \\
More intensive usage of manure & 63,64 \\
Process the land opposite the contour & 19,69 \\
Application of intercropping or rotating & 19,69 \\
cropping systems & \\
\hline
\end{tabular}

\section{Level of Household Food Security}

Food security level of cassava farming households in Lampung, Indonesia presented in Table 2. Level of household food security in this study was determined by measuring it through four components of household food security, namely sufficiency of food availability, stability of food availability, accessibility to food, and food quality. Based on the result, food security level of most cassava farming households $(90.90 \%)$ was categorized as less secure, and those of $9.09 \%$ were food insecure (Table 2). In fact, no cassava farmer was found to be food secure. This finding shows that food availability of cassava farming households was less continuous $(90.90 \%)$ and not continuous $(9.09 \%)$ with good quality of food consumption. It is possible that cassava farming households with less continuous and not continuous food availability did not directly obtain their food through production, but they bought them (indirect). In other words, accessibility of all cassava farmers $(100 \%)$ were obtained indirectly since cassava produced by farmers were sold to tapioca factory in Central Lampung Regency. Moreover, less continuous availability of food occurred because food stocks owned by farmers could only be consumed for less than 240 days with eating frequency of 2 times a day and plant protein as protein source. This finding is not in agreement with that of Murnati et al. (2017) on organic farmers in Tanggamus Regency that concluded that many $(60 \%)$ of organic rice farmers were food secure during rainy season and $48.00 \%$ were during dry season.

Table 2: Food security level of cassava farming households in Lampung, Indonesia

\begin{tabular}{|c|c|c|}
\hline Description & Number (household) & Percentage (\%) \\
\hline \multicolumn{3}{|l|}{ Food Availability } \\
\hline - $\quad$ Availability $\geq 240$ hari & 52 & 78.78 \\
\hline - $\quad$ Availability $1-239$ hari & 14 & 21.21 \\
\hline - No availability & - & - \\
\hline \multicolumn{3}{|l|}{ Food Stability } \\
\hline - Stable & 32 & 48.48 \\
\hline - $\quad$ Less stable & 28 & 42.42 \\
\hline - $\quad$ Unstable & 6 & 9.09 \\
\hline \multicolumn{3}{|l|}{ Accessibility } \\
\hline - $\quad$ Direct & - & - \\
\hline - Indirect & 66 & 100.00 \\
\hline \multicolumn{3}{|l|}{ Continuity } \\
\hline - Continuous & - & - \\
\hline - $\quad$ Less continuous & 60 & 90.90 \\
\hline - $\quad$ Not continuous & 6 & 9.09 \\
\hline \multicolumn{3}{|l|}{ Food Security Level } \\
\hline - $\quad$ Food secure & - & - \\
\hline - Less secure & 60 & 90.90 \\
\hline - $\quad$ Food insecure & 6 & 9.09 \\
\hline
\end{tabular}


Creative Commons User License: CC BY-NC-ND

Abstracted by: EBSCOhost, Electronic Journals Service (EJS), Google Scholar, Journal Seek, Scientific Commons,

Food and Agricultural Organization (FAO), CABI and Scopus
Journal of Agricultural Extension

Vol. 23 (2) April, 2019

ISSN(e): 24086851; ISSN(Print); 1119944X

http://journal.aesonnigeria.org

http://www.ajol.info/index.php/jae

Email: editorinchief@aesonnigeria.org

http://eoi.citefactor.org/10.11226/v23i2

Based on the indicators of food security in terms of food stability, it was found that cassava farmers were mostly stable (48.48 \%) and less stable $(42.42 \%)$ on food security. This result indicates that most cassava farmers had adequate food availability with eating frequency of 2-3 times a day, while none of the households had eating frequency of 1 meal per day. However, farm households were categorized into unstable category because they had no food stock as they only purchased food with low economic resource. It means that purchasing power owned by cassava farmers to meet their needs for food is only enough for daily food consumption. According to a study, the majority of farmers $(78.78 \%)$ had adequate food availability for more than 240 days or 8 months, while the rest of $21.21 \%$ had food stocks for 239 days or 8 months. This situation would enable cassava farmers consume food with frequency of 2-3 times a day. Continuity of food stock is also affected by land ownership that is used by farmers to fulfil their food needs, where farmers with sufficient food availability will be able to consume food regularly three times a day.

Conversely, farmers with low amount or no staple food availability is considered to have poor food stability.

Relationships between food security of cassava farming households, food availability, food accessibility, and food consumption were assessed. It is known that food availability and food accessibility are the indicators of food security that depict the situation of farm household, while food consumption is the indicator of direct impact of food security, reflected by the quantity and quality of farm household food consumption. The result found that significant relationship was found $78.78 \%$ (Table 2) between household food security, food consumption pattern and exogenous variables (household size, access to food family expenditure, energy consumption (Novianto et al., 2015), and protein consumption (Bahta et al., 2017).

\section{Effect of Climate Change Adaptation Strategy and Other Factors on Food Security of Cassava Farming Household}

Factors affecting food security of cassava farming households was assessed using the theory of household consumption through the analysis of Ordinal Logit Regression. Factors that influence food security of cassava farming households are adaptation strategy to climate change in food security, adaptation strategy to climate change in consumption, price of rice, price of sugar, price of egg, price of cooking oil, price of urea fertilizer, price of seed, land size, income, and knowledge of climate change. In Ordinal Logit, the first step to apply is categorizing the food security level to be used: according to the food security definition described by Food and Agriculture Organization (FAO) (2018) the category consists of: food secure (3), less secure (2), and food insecure. (1). Analysis result of factors affecting food security of cassava farming households is presented in Table 3.

Change and amount of household expenditure on food is related to the level of food price than can be afforded by the household. Changes in applicable price, particularly price of staple food will highly affect the amount and change in household expenditure. This situation was found in study conducted on cassava farming households where the effect of several independent variables on food security was observed. 
Creative Commons User License: CC BY-NC-ND

Abstracted by: EBSCOhost, Electronic Journals Service (EJS), Google Scholar, Journal Seek, Scientific Commons,

Food and Agricultural Organization (FAO), CABI and Scopus
Journal of Agricultural Extension

Vol. 23 (2) April, 2019

ISSN(e): 24086851; ISSN(Print); 1119944X

http://journal.aesonnigeria.org

http://www.ajol.info/index.php/jae

Email: editorinchief@aesonnigeria.org

http://eoi.citefactor.org/10.11226/v23i2

affecting food security level of cassava farming households

\begin{tabular}{lrrll}
\hline \multicolumn{1}{c}{ Variable } & Coefficient & Std.Error & $\begin{array}{l}\text { Z- } \\
\text { Statistic }\end{array}$ & OR \\
\hline Cutt off/Limit 1 & -24.30945 & & & \\
Cutt off/Limit 2 & -7.748764 & & & \\
adaptation & 1.559649 & .908559 & $1.72^{*}$ & 4.757153 \\
climate & -2.824248 & 2.36852 & -1.19 & .0593533 \\
area & 5.368925 & 2.408452 & $2.23^{* *}$ & 214.6319 \\
pfertilizer & -.0088286 & .0074534 & -1.18 & .9912103 \\
p seed & .0220323 & .0260415 & 0.85 & 1.022277 \\
price & -.004378 & .0018826 & $-2.33^{* *}$ & .9956315 \\
p cooking oil & .0003773 & .0006484 & 0.58 & 1.000377 \\
psugar & -.0007834 & .0010078 & -0.78 & .9992169 \\
pegg & .000497 & & 1.54 & 1.000497 \\
income & $6.83 e-08$ & .0003236 & 0.91 & 1 \\
\multicolumn{7}{l}{ LR index (Pseudo-R2) } & $7.49 e-08$ & & \\
LR statistic (14df) & & & 0.7095 & \\
Prob (LR stat) & & & 0.000 & \\
\hline
\end{tabular}

$\left.\left.{ }^{* *} P \leq 0.05\right),{ }^{*} P \leq 0.10\right)$,

Based on result on Table 3, the model used in this study obtained Pseudo $\mathrm{R}^{2}$ value of 0.7095 which means that the independent variables in the model are able to explain about $70.95 \%$ on food security, while the rest of $29.05 \%$ is explained by other variables excluded in the model. Goodness of Fit is shown by LR X ${ }^{2}$ value of 49.38 that is significant at error level of $1 \%$ with Chi Square probability value of $.0 .0000<0.01$, means that independent variables all together significantly affect food security, thus it is considered a good model. The number of significant coefficients of estimation (independent variables) was 3 out of 10 variables expected.

The level of food security is categorized based on the cut off value or limit under the assumption of ceteris paribus. Level of food security of cassava farming households at different categories in unit of utility is written as follows: probability of food secure: $\operatorname{Pr}$ (DKP .>-7.748764), probability of less secure: $\operatorname{Pr}(-24.30945<\mathrm{DKP} \leq-7.748764)$, probability of food insecure: $\operatorname{Pr}(\mathrm{DKP} \leq-$ 24.30945).

Based on estimation result of Ordinal Logit Model, there are two categories of odds percentage, those are: (a) percentage of positive odds, that is for every 1 unit increase in independent variable, there will be increasing odds or probability of food security level, and (b) percentage of negative odds which means for every 1 unit increase in independent variable, there will be decreasing odds or probability of food security level.

\section{Percentage of positive odds}

Table 3 depicts the percentage of positive odds in the variable of adaptation strategy in farming and land. The positive logit value indicates that increase in level of food strategy and land size will increase the probability of food security level of cassava farming households. The OR value of variable of climate change adaptation strategy of 4.757153 means for every 1 unit increase in 
Creative Commons User License: CC BY-NC-ND

Abstracted by: EBSCOhost, Electronic Journals Service (EJS), Google Scholar, Journal Seek, Scientific Commons,

Food and Agricultural Organization (FAO), CABI and Scopus
Journal of Agricultural Extension

Vol. 23 (2) April, 2019

ISSN(e): 24086851; ISSN(Print); 1119944X

http://journal.aesonnigeria.org

http://www.ajol.info/index.php/jae

Email: editorinchief@aesonnigeria.org

http://eoi.citefactor.org/10.11226/v23i2

climate change adaptation strategy in farming performed by farmers with assumption of independent variable remains constant (ceteris paribus), there will be increase in probability of food security of 4.757153 . To indicate that cassava farmers in the study area have the ability to adjust or adapt to climate change by applying the strategy, thus loss that occurs due to extreme climate change will not lead to significant impact on the declining production and farmer income. It is understandable because most cassava farmers meet their food needs through indirect access or purchasing (since the land owned is planted with cassava), any strategies applied by farmers to adjust or to adapt to climate change will result in indirect effect (positive) in increasing food security of cassava farming household.

Climate change adaptation is the ability of a system including ecosystem, socio-economy and institutional system, to adjust to the impact of unpredicted climate, weather, and season (climate change). Therefore, adaptation to the impact of climate change is urgently required to ensure farmers maintain their farming productivity. Adaptation technologies that may be applied by farmers include adjustment of planting time, the use of drought tolerant variety, soaking, salinity, and the development of water management technology (Trenberth et al., 2014; Fita et al., 2015). Adaptation technology or strategy conducted by cassava farmers against climate change in study area was applied in various activities, namely intensive use of manure, reducing the use of chemical input, increasing weeding intensity, planting in early rainy season, use of the recommended planting distance, scheduling harvesting period, changing the planting time and more discipline in applying plant rotation. The strategy applied by cassava farmers aims to control climate change that will have impact on cassava farming (Burney et al., 2014; Mupikati et al., 2017). In general, cassava farmers (65.15\%) neither know nor understand climate change at micro level and only $34.85 \%$ of cassava farmers have already known and understood climate change at micro level. However, cassava farmers are able to observe changes in several climate elements such as warmer temperature, slow start to rainy season, frequent drought, and very strong wind.

Variable of land size that obtained OR value of 214.6319 means for every increase of 1 (one) ha in land size with the assumption that other variables remain constant (ceteris paribus), there will be probability of increase in food security of cassava farming households of 214.6319 . Increase in land size will further increase cassava production which eventually will raise farmers income and strengthen purchasing power of farmers that will have impact on the increasing food availability of farm households.

To conclude, those conditions will improve food security of cassava farming households. In average, cassava farmers worked in their own farming aresa with total of 1.42 ha. Based on calculation, cassava farming is profitable as seen from the $\mathrm{R} / \mathrm{C}$ ratio that is greater than one. It shows that cassava farming performed by farmers in Lampung Province is quite profitable.

\section{Percentage of negative odds}

Based on Table 3, the variable that obtained negative odds value is the price of rice. The negative value of coefficient of logit indicates that an increase in rice price will decrease the probability of food security level of cassava farming households. The OR value of rice price variable of 0.9956315 means for every one rupiah increase in rice price with assumption that other variables remain constant (ceteris paribus), there will be probability of declining food security of farm households of 0.9956315 . It means that increasing price of rice will significantly have impact on changes in food expenditure pattern of cassava farming households, namely the declining rice expenditure that will lower the rice stock and energy consumed. In other word, decrease in farm 
Creative Commons User License: CC BY-NC-ND

Abstracted by: EBSCOhost, Electronic Journals Service (EJS), Google Scholar, Journal Seek, Scientific Commons,

Food and Agricultural Organization (FAO), CABI and Scopus
Journal of Agricultural Extension

Vol. 23 (2) April, 2019

ISSN(e): 24086851; ISSN(Print); 1119944X

http://journal.aesonnigeria.org

http://www.ajol.info/index.php/jae

Email: editorinchief@aesonnigeria.org

http://eoi.citefactor.org/10.11226/v23i2

household food (rice) consumption will directly reflect the declining food security level of cassava farming households. This situation is in line with the statement of Ramachandran (2013) who mentioned that the extent of change in budget allocation for food expenditure will determine the extent of fulfilment of food and energy required by farming households which will further have impact on nutritional status. It is known that cassava farmers in research site have indirect access to food, especially staple food (rice), thus they highly depend on the market price of rice to meet their needs for rice consumption.

The result concluded that factors affecting food security in Pontianak Regency of West Kalimantan consisted of land, price of rice, price of cooking oil, price of egg, and farmer's age. The study conducted by Murniati et al. (2016) on food security of organic rice farming household in rain-fed land of Tanggamus Regency found that the price of rice had positive OR value and significantly affected food security since they produced the rice themselves. Thus, it will increase the price of rice, rice farmers' income and finally improve food security of farming households.

\section{Conclusion and Recommendations}

On the average, there are five adaptation and anticipation strategies to climate change applied by farmers in farming. Cassava farming households are mostly less secure. Climate change strategy, land size, and price of rice affected food security level of cassava farming households. To improve food security level, cassava farming households should increase staple food availability to meet the adequate number by increasing food stock as well as food quality and continuity to consume.

\section{References}

Ali, S., Liu, Y., Ishaq, M., Shah, T., Abdullah, Ilyas, A., \& Din, I. (2017). Climate Change and Its Impact on the Yield of Major Food Crops: Evidence from Pakistan. Foods, 6(6): 39. doi:10.3390/foods6060039

Bahta, S., Wanyoike, F., Katjiuongua, H., \& Marumo, D. (2017). Characterisation of food security and consumption patterns among smallholder livestock farmers in Botswana. Agriculture \& Food Security, 6:65 doi : 10.1186/s40066-017-0145-1.

Burney, J., Cesano, D., Russell, J., La Rovere, E. L., Corral, T., Coelho, N. S., \& Santos, L. (2014). Climate change adaptation strategies for smallholder farmers in the Brazilian Sertão. Climatic Change, 126(1-2): 45-59. doi:10.1007/s10584-014-1186-0.

Food and Agriculture Organization (2016). Climate change and food security: risks and responses . Food and agriculture organization of the United Nations, Rome. Retrieved from http://www.fao.org/3/a-i5188e.pdf

Food and Agriculture Organization (2018). The state of foof security and nutritionin the world. Building climate resilience for food security and nutrition. Food and agriculture organization of the United Nations, Rome. Retrieved from http://www.fao.org/3/19553EN/i9553en.pdf

Fita, A., Rodríguez-Burruezo, A., Boscaiu, M., Prohens, J., \& Vicente, O. (2015). Breeding and Domesticating Crops Adapted to Drought and Salinity: A New Paradigm for Increasing Food Production. Frontiers in Plant Science, 6.doi:10.3389/fpls.2015.00978.

Hakim, L. \& Herdiansah, D. (2017).Food security production challenges in Indonesia as Impact of Global Climate Change. International Journal of Environmental \& Agriculture Research (IJOEAR), 3(7): $26-32$.

Kirby, J. M., Mainuddin, M., Mpelasoka, F., Ahmad, M. D., Palash, W., Quadir, M. E., \& Hossain, M. M. (2016). The impact of climate change on regional water balances in Bangladesh. 
Creative Commons User License: CC BY-NC-ND

Abstracted by: EBSCOhost, Electronic Journals Service (EJS), Google Scholar, Journal Seek, Scientific Commons,

Food and Agricultural Organization (FAO), CABI and Scopus
Journal of Agricultural Extension

Vol. 23 (2) April, 2019

ISSN(e): 24086851; ISSN(Print); 1119944X

http://journal.aesonnigeria.org

http://www.ajol.info/index.php/jae

Email: editorinchief@aesonnigeria.org

http://eoi.citefactor.org/10.11226/v23i2

$$
\text { Climatic Change, 135(3-4): 481-491.doi:10.1007/s10584-016-1597-1. }
$$

Mupakati, T., \& Tanyanyiwa, V. I. (2017). Cassava production as a climate change adaptation strategy in Chilonga Ward, Chiredzi District, Zimbabwe. Jàmbá: Journal of Disaster Risk Studies, 9(1).doi:10.4102/jamba.v9i1.348

Murniati,K. , Mulyo, J.H,, Irham., \& Hartono, S. (2016). Farmers' Adaptation Strategies to Climate Change and Food Security of Households of Organic Rice Farmers in Tanggamus Regency (Ordinal Logit Model Approach). Proceeding of International Conference on Climate Change. doi: 10.15608/iccc.y2016.546

Novianto,D., Gao, W., \& Kuroki, S. (2015). Review on People's Lifestyle and Energy Consumption of Asian Communities: Case Study of Indonesia, Thailand, and China. Energy and Power Engineering, 7: 465-476.

Quincieu, E. (2015). Agriculture, Natural Resources, And Environment Sector Assessment (Summary). Asian Development Bank 1-7.

Rahmah, M. (2015). The protection of Agricultural product under Geographical Indication Alternative Too for Agricultural in Indonesia. Journal of Inttelctual Property Rights 22: 90-13.

Ramachandran, P. (2013). Food \& nutrition security: Challenges in the new millennium. Indian Journal of Medicine Research, 138(3): 373-382.

Saediman, H., Limi, M.A., Rosmawaty., Arimbawa, P. \& Indarsyih. 2016. Cassava Consumption and Food Security Status among Cassava Growing Households in Southeast Sulawesi. 15 (12): 1008-1016. doi : 10.3923/pjn.2016.1008.1016

Trenberth, K.E., Dai, A., van der Schrier, G., Jones, P.D., Barichivich, J., Briffa, K.R. \& Sheffield, J. (2014). Global warming and changes in drought. Nature and Climate Change, 4: 17-22. doi: $\underline{10.1270 / j s b b s .64 .60}$. 